\title{
Revival of the Name Vibrio vulnificus
}

\author{
J. J. FARMER III \\ Enteric Section, Center for Disease Control, Atlanta, Georgia 30333
}

\begin{abstract}
The name Vibrio vulnificus (Reichelt et al.) Farmer was validly published as a new combination in The Lancet, October, 1979. However, the editors of the Bacteriological Code did not include a mechanism to validate those names validly published in the literature outside the International Journal of Sys. tematic Bacteriology during October, November, or December, 1979. Thus, all these new names and combinations lost standing because they could not be included on the Approved Lists of Bacterial Names. V. vulnificus comb. nov. is hereby proposed as a revived name so it can again have standing in nomenclature.
\end{abstract}

In October, 1979, a proposal was made to transfer the bacterium known as Beneckea vulnifica Reichelt, Baumann, and Baumann 1979 $(3,4)$ (synonym $=$ " $\mathrm{L}^{+}$vibrio") to the genus Vibrio, where its name became Vibrio vulnificus comb. nov. (1). This new combination was immediately brought to the attention (in a letter dated 23 November 1979) of the editor of the International Journal of Systematic Bacteriology (IJSB) for validation. However, the Bacteriological Code, which specifies the mechanism for validating new names and new combinations, did not include a way to validate names published in the literature (outside the IJSB) during October, November, or December, 1979. The name $V$. vulnificus comb. nov. was published during this time and could not be validated in the IJSB in time to appear on the Approved Lists of Bacterial Names (5). Through this oversight in the Bacteriological Code, V. vulnificus comb. nov. lost standing in nomenclature. The name Vibrio vulnificus is hereby revived as a new combination with its original meaning (1). The type strain remains ATCC $27562(3,4)$. The descriptions given previously by Hollis et al. for " $\mathrm{L}^{+}$vibrio" (2) and by Reichelt et al. (4) for Beneckea vulnifica apply to Vibrio vulnificus comb. nov., nom. rev.

\section{Reprint Requests}

Address reprint requests to: Center for Disease Control, Attn. J. J. Farmer III, Building 1, Room B341, Atlanta, GA 30333 .

\section{LITERATURE CITED}

1. Farmer, J. J., III. 1979. Vibrio ("Beneckea") vulnificus, the bacterium associated with sepsis, septicaemia and the sea. Lancet 2:903.

2. Hollis, D. G., R. E. Weaver, C. N. Baker, and C. Thornsberry. 1976. Halophilic Vibrio species isolated from blood cultures. J. Clin. Microbiol. 3:425-431.

3. International Journal of Systematic Bacteriology. 1979. Validation of the publication of new names and new combinations previously effectively published outside the IJSB. List no. 2. Int. J. Syst. Bacteriol. 29:7980.

4. Reichelt, J. L., P. Baumann, and L. Baumann. 1976. Study of genetic relationships among marine species of the genera Beneckea and Photobacterium by means of in vitro DNA/DNA hybridization. Arch. Microbiol. 110:101-120.

5. Skerman, V. B. D., V. McGowan, and P. H. A. Sneath. 1980. Approved lists of bacterial names. Int. J. Syst. Bacteriol. 30:225-420. 